\title{
Sintesis dan Karakterisasi Nanopartikel Zn Menggunakan Kitosan sebagai Reduktor
}

\author{
Astuti Amin*, Sri Reski Ananda \\ Sekolah Tinggi Ilmu Farmasi Makassar, Makassar, 90241, Indonesia
}

INFO ARTIKEL

\begin{tabular}{l}
\hline Diterima 3 Oktober 2020 \\
Disetujui 26 Oktober 2020 \\
\hline Key word: \\
Shrimp shell, chitosan, \\
reduction, characterization, $\mathrm{Zn}$ \\
nanoparticles \\
\hline Kata kunci: \\
Kulit udang, kitosan, reduksi, \\
karakterisasi, nanopartikel $\mathrm{Zn}$
\end{tabular}

email:amin.astuti@gmail.com

\begin{abstract}
A B S T R A C T
Zn nanoparticles is a material that is widely used in the pharmaceutical and cosmetic industry, as a sunscreen, skin whitening and anti-aging. The purpose of this study was to synthesize $\mathrm{Zn}$ nanoparticles using chitosan as a reducing agent by using chemical reduction methods and determining the ratio of the concentration of chitosan to the reducing power of $\mathrm{Zn}$ nanoparticles. In this study used shrimp shell waste which was synthesized in several stages, deproteination, demineralization, and deacetylation. The synthesis results obtained by $22.8 \%$ chitosan rendamen with a deacetylation degree of $85 \%$. Chitosan is used as a reducing agent to synthesize zinc nanoparticles against $\mathrm{Zn}$ ions in a $1000 \mathrm{ppm} \mathrm{ZnO}$ solution. The measurement using Atomic Absorption Spectroscopy (AAS) show that concentrate of $\mathrm{Zn}$ in solution synthesis result of $13,88 \mathrm{mg} / \mathrm{l}$, based on the UV-Vis spectrofotometry obtained maximum wavelength of 355,71 $\mathrm{nm}$ and absorbance of 0,062, the shapes of the nanoparticles obtained tend to aggregate. Based on measurements by Particle Size Analyzer (PSA) which has been synthesized Zn nanoparticles have an average size of the particles in the sample is $213,41 \mathrm{~nm}$.
\end{abstract}

\section{ABSTRAK}

Nanopartikel Zn merupakan material yang banyak digunakan dalam industri farmasi dan kosmetik, sebagai tabir surya, pemutih kulit, dan antiaging. Tujuan dari penelitian ini untuk mensintesis nanopartikel $\mathrm{Zn}$ menggunakan kitosan sebagai reduktor dengan metode reduksi kimia dan menentukan perbandingan konsentrasi kitosan terhadap daya reduksi $\mathrm{Zn}$ nanopartikel. Pada penelitian ini digunakan limbah cangkang udang yang disintesis dengan beberapa tahap yaitu deproteinasi, demineralisasi, dan deasetilasi.Hasil sintesis diperoleh Rendamen kitosan 22,8\% dengan nilai derajat deasetilasi adalah $85 \%$. Kitosan digunakan sebagai reduktor untuk mensintesis nanopartikel zink terhadap ion Zn dalam larutan ZnO 1000 ppm . Dari hasil pengukuran dengan spektroskopi serapan atom (SSA) diperoleh kadar $\mathrm{Zn}$ dalam larutan hasil sintesis sebesar 13,88 mg/l, berdasarkan spektrofotometri UV-Vis diperoleh panjang gelombang maksimum 355,71 $\mathrm{nm}$ dan absorbansi sebesar 0,062 dengan morfologi cenderung beragregasi.. Berdasarkan pengukuran dengan Particle Size Analyzer (PSA) nanoptartikel Zn yang telah disintesis memiliki ukuran ratarata partikel dalam sampel yaitu $213,41 \mathrm{~nm}$.

\section{Pendahuluan}

Indonesia merupakan negara maritim yang memiliki hasil laut yang berlimpah seperti udang, bekicot, dan kepiting [1]. Sebagai salah satu pengekspor udang terbesar, Indonesia juga menghasilkan banyak limbah dari cangkang udang [2]. Seiring dengan semakin majunya ilmu pengetahuan limbah udang yang berasal dari kulit, kepala dan ekornya dapat dimanfaatkan dan diolah menjadi produk baru yang bernilai ekonomis. Salah satu kandungan kulit udang yang bisa dimanfaatkan adalah kitin dan kitosan $[3,4]$.

Kitosan adalah suatu polisakarida berbentuk linier yang terdiri dari monomer Nasetilglukosamin (GlcNAc) dan D-glukosamin (GlcN) [3]. Bentukan derivatif deasetilasi dari polimer ini adalah kitin. Kitosan memiliki manfaat yang banyak bagi pangan, agrikultur, dan medis. Karena sifat-sifa istimewa seperti 
mukoadhesif, biokompatibel, biodegradabel nontoksik dan tingkat imonogenisitas yang rendah [5]. Nanopartikel merupakan suatu partikel dengan ukuran nanometer, yaitu sekitar 10-1000 nm. Beberapa material logam yang banyak disintesis menjadi nano partikel adalah AgNO3, $\mathrm{ZnO}$, dan $\mathrm{TiO}$. Nanopartikel Oksida Seng $(\mathrm{ZnO})$ merupakan material yang dapat digunakan pada industri kosmetik, misalnya sebagai tabir surya, pemutih kulit, dan antiaging. Berbagai merk dari produk pun semakin berlomba-lomba dalam upaya pengembangan teknologi nanopartikel $\mathrm{ZnO}$ [6,7]. Berdasarkan latar belakang diatas, maka dilakukan sintesis nanopartikel $\mathrm{Zn}$ dengan kitosan sebagai pereduksi dengan konsentrasi kitosan yang berbeda.

\section{Bahan dan Metode}

Bahan dalam penelitian ini antara lain : ragi Endomycopsis fibuligera, natrium sitrat monohidrat $\left(\mathrm{Na}_{3} \mathrm{C}_{6} \mathrm{H}_{5} . \mathrm{H}_{2} \mathrm{O}\right)$, natrium dihidrogen phosfat $\left(\mathrm{NaH}_{2} \mathrm{PO}_{4}\right)$, garam rochelle $\left(\mathrm{C}_{4} \mathrm{H}_{4} \mathrm{KNaO}_{6} .4 \mathrm{H}_{2} \mathrm{O}\right)$, bovine serum albumin (BSA), dinitro salisilic acid (DNSA), glukosa anhidrat $\left(\mathrm{C}_{6} \mathrm{H}_{12} \mathrm{O}_{6}\right)$, tambaga sulfat $\left(\mathrm{CuSO}_{4} .5 \mathrm{H}_{2} \mathrm{O}\right)$, natrium karbonat $\left(\mathrm{Na}_{2} \mathrm{CO}_{3}\right)$, natrium hidroksida $(\mathrm{NaOH})$, larutan buffer $\mathrm{pH}$ 5 dan $\mathrm{pH} 4,8$, fenolfolin-ciocalteus $1 \mathrm{~N}$, etanol $(\mathrm{CH} 2 \mathrm{H} 5 \mathrm{OH})$, magnesium klorida heksahidrat $\left(\mathrm{MgCl}_{2} .6 \mathrm{H}_{2} \mathrm{O}\right)$, kalsium klorida dihidrat $\left(\mathrm{CaCl}_{2} .2 \mathrm{H}_{2} \mathrm{O}\right)$, tepung jagung, ektrak tauge, aluminium foil, ekstrak ragi, akuades, agar bakto, kapas, tali dan kain kasa, kertas $\mathrm{pH}$, natrium klorida $(\mathrm{NaCl})$, kalium klorida $(\mathrm{KCl})$, spiritus, aquabidest.

\section{Pembuatan kitin}

Proses Deproteinasi dilakukan pada suhu $60-70^{\circ} \mathrm{C}$ dengan menggunakan larutan $\mathrm{NaOH} 1$ $\mathrm{M}$ dengan perbandingan serbuk kulit udang dengan $\mathrm{NaOH}$ 1:10 sambil diaduk selama 60 menit. Kemudian campuran dipisahkan dengan disaring untuk diambil endapannya.

\section{Pencucian dan pengeringan}

Pencucian endapan dilakukan dengan menggunakan aquadest sampai $\mathrm{pH}$ netral. Selanjutnya disaring untuk diambil endapannya dan dikeringkan.

\section{Demineralisasi}

Penghilangan mineral dilakukan pada suhu $25-30^{\circ} \mathrm{C}$ dengan menggunakan larutan $\mathrm{HCl} 1 \mathrm{M}$ dengan perbandingan sampel dengan larutan $\mathrm{HCl}=1: 10$ sambil diaduk selama 120 menit. Kemudian disaring untuk diambil endapannya.

\section{Pencucian dan pengeringan}

Pencucian endapan dilakukan dengan menggunakan aquadest sampai $\mathrm{pH}$ netral. Kemudian disaring dan endapan dikeringkan [8].

\section{Deasetilasi Kitin menjadi Kitosan}

Kitin yang telah dihasilkan pada proses demineralisasi, ditambahkan larutan $\mathrm{NaOH}$ dengan konsentrasi $50 \%$ pada suhu $90-100^{\circ} \mathrm{C}$ diaduk dengan kecepatan konstan selama 60 menit. Kemudian disaring, endapan dicuci dengan aquadest lalu ditambah larutan $\mathrm{HCl}$ encer sampai $\mathrm{pH}$ netral kemudian dikeringkan. Hasil pengeringan dianalisis dengan FTIR, Kemudian dihitung Derajatt Deasetilasi (DD) [9].

\section{Karakterisasi Kitin dan Kitosan \\ Rendamen Kitin dan Kitosan}

Rendamen merupakan persentasi dari perbandingan serbuk kitin dan kitosan terhadap bobot cangkang udang sebelum mengalami perlakuan. Perhitungan persentase rendamen menggunakan persamaan 1 dan persamaan 2:



\section{Derajat deasetilasi}

Derajat deasetilasi adalah persentase gugus asetil yang berhasil dihilangkan selama proses deproteinasi kitin, dimana kitin diberi perlakuan dengan menambahkan $\mathrm{NaOH} 50 \%$ yang menyebabkan terhidrolisisnya gugus asetil dan gugus asetamida pada kitin. Derajat deasetilasi dapat ditentukan dari spektrum serapan spektroskopi IR dengan metode garis dasar. Puncak tertinggi dicatat dan diukur dari garis dasar yang dipilih. Perbandingan dari bilangan gelombang antara serapan pita amida (1655 cm-1) dengan serapan pita hidroksi (3450 $\mathrm{cm}-1)$. 
Sintesis Nanopartikel Zn kitosan

Sebanyak $25 \mathrm{mg}, 75 \mathrm{mg}, 125 \mathrm{mg}, 175 \mathrm{mg}$, dan 225 mg kitosan masing-masing dilarutkan dengan $100 \mathrm{ml}$ asam asetat 1\%. Kemudian ditambahkan larutan $\mathrm{ZnO}$ dengan konsentrasi 1000 ppm, kemudian diaduk menggunakan magnetik stirrer selama 1 jam pada suhu $80^{\circ} \mathrm{C}$. Kemudian dianalisis dengan spektrofotometri UV-VIS.

\section{Karakterisasi Nanopartikel Zn}

Analisis Spektrofotometer Atomic Absorption Spectroscopy (AAS) Sebanyak $5 \mathrm{ml}$ sampel dimasukkan dalam kuvet lalu diukur panjang gelombangnya menggunakan alat spektrofotometer serapan atom [7].

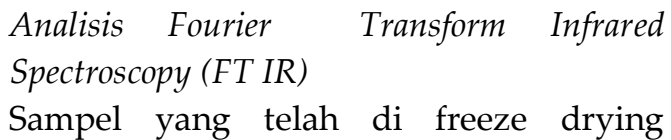
ditimabang $2 \mathrm{mg}$ dicampur dengan $100 \mathrm{mg}$ $\mathrm{KBr}$ untuk dibuat pelet dengan pencetak vakum. Pelet yang terbentuk dikenai sinar infra merah dengan range bilangan gelombang 4.000-400 cm-1. Latar belakang absorpsi dihilangkan dengan cara pelet $\mathrm{KBr}$ dijadikan satu pada setiap pengukuran.

Analisis Particle Size Analyzer (PSA)

Sebelum pengukuran sampel, aquadest dimasukkan ke dalam fluid tank sebagai baseline. Sampel dimasukkan ke dalam fluid tank tetes demi tetes hingga konsentrasi mencukupi. Hasil muncul ditandai dengan gerafik yang dihasilkan.

Analisis Scanning Electron Microscope (SEM)

Sampel hasil freeze drying diamati morfologinya menggunakan SEM dengan cara sampel diletakkan pada plat aluminium yang memiliki dua sisi, kemudian dilapisi dengan lapisan emas setebal $100 \mathrm{~nm}$ dengan waktu coating \pm 30 detik. Sampel yang telah dilapisi lalu diamati dengan menggunakan alat Scanning Electron Microscope (SEM).

\section{Hasil dan Pembahasan}

\section{Uji Karakteristik Kitosan}

Pada penelitian ini dilakukan Pembuatan kitosan dengan cara menghilangkan gugus asetil (deasetilasi) dari kitin menggunakan larutan basa $\mathrm{NaOH}$ pada konsentrasi 50\% (b/v). Proses deasetilasi dalam basa kuat panas menyebabkan hilangnya gugus asetil pada kitin melalui pemutusan ikatan antara karbon pada gugus asetil dengan nitrogen pada gugus amin. Reaksi pembentukan kitosan dari kitin merupakan reaksi hidrolisa suatu amida oleh suatu basa. Kitin bertindak sebagai amida dan $\mathrm{NaOH}$ sebagai basa. Mula-mula terjadi reaksi adisi, dimana gugus $\mathrm{OH}$ - masuk ke dalam gugus $\mathrm{NHCOCH}$.,kemudian terjadi eliminasi gugus $\mathrm{CH}_{3} \mathrm{COO}$-sehingga dihasilkan suatu amina yaitu kitosan [5]. Karakterisasi kitosan yang dilakukan meliputi uji kelarutan dalam asam asetat $1 \%$, tekstur, warna, serta DD (Derajat Deasetilasi) [10]. Hasil karakterisasi kitosan dan yang diperoleh dari penelitian dibandingkan dengan standar mutu internasional kitosan yang dapat dilihat pada tabel 1. Sedangkan rendamen kitosan yang didapatkan sebesar $22,8 \%$.

Tabel 1. Hasil uji karakteristik kitosan

\begin{tabular}{|c|c|c|}
\hline Parameter & $\begin{array}{l}\text { Standar } \\
\text { (SI) }\end{array}$ & Hasil \\
\hline \multicolumn{3}{|l|}{ Rendamen } \\
\hline -Kitin & - & $42,3 \%$ \\
\hline -Kitosan & - & $22,8 \%$ \\
\hline $\begin{array}{l}\text { Kelarutan } \\
\text { dalam } \\
\text { asam } \\
\text { asetat } 1 \%\end{array}$ & Larut & Larut \\
\hline $\begin{array}{l}\text { Morfologi } \\
\text { partikel }\end{array}$ & $\begin{array}{l}\text { Serbuk } \\
\text { Atau serpihan }\end{array}$ & Serpihan \\
\hline Warna & $\begin{array}{l}\text { Putih sampai } \\
\text { kuning pucat }\end{array}$ & $\begin{array}{l}\text { Putih } \\
\text { kekuningan }\end{array}$ \\
\hline $\begin{array}{l}\text { DD } \\
\text { (Derajat } \\
\text { deasetilasi) }\end{array}$ & $>70 \%$ & $85 \%$ \\
\hline
\end{tabular}

Kelarutan kitosan dalam asam asetat merupakan salah satu parameter yang dapat dijadikan sebagai standar penilaian mutu kitosan. Semakin tinggi kelarutan kitosan dalam asam asetat $1 \%$ berarti mutu kitosan yang dihasilkan semakin baik [11-13]. Kitosan yang dihasilkan memiliki kelarutan yang sempurna dalam asam asetat 1\%. Kitosan selanjutnya diuji derajat deasetilasinya untuk memastikan kitosan yang dihasilkan telah memenuhi spesifikasi (derajat deasetilasi 
$>70 \%$ ). Pengujian kitosan dilakukan dengan menggunakan metode FTIR. Berdasarkan perhitungan, maka diperoleh derajat deasetilas kitosan adalah $85 \%$. Kitosan yang dihasilkan dari penelitian ini telah memenuhi spesifikasi derajat deasetilasi minimum karena lebih besar dari $70 \%$. Derajat deastilasi yang tinggi menyebabkan gugus asetil pada kitin yang berubah menjadi gugus amina yang lebih reaktif . dimana Gugus amina lebih reaktif dibandingkan dengan gugus asetil karena adanya pasangan elektron bebas pada atom nitrogen dalam struktur kitosan [5].

Sintesis nanopartikel zink dilakukan dengan mencampur larutan $\mathrm{ZnO}$ dengan kitosan (gambar 1). Kemudian dilakukan penentuan jumlah optimum kitosan dalam pembentukan nanopartikel $\mathrm{Zn}$ dengan menggunakan spektrofotometer UV-Vis yang dioperasikan dengan range 200-500 nm.

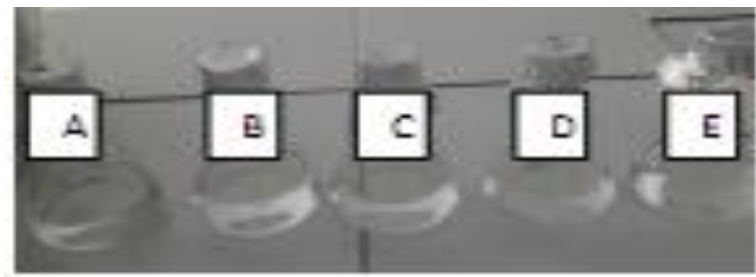

Gambar 1. Larutan $\mathrm{ZnO} 1000$ ppm yang direduksi oleh kitosan. (A) $25 \mathrm{mg}$, (B) $75 \mathrm{mg}$, (C) $125 \mathrm{mg}$, (D) $175 \mathrm{mg}$, (E) $225 \mathrm{mg}$.

Dari hasil pengukuran dengan spektrofotometer UV-Vis menunjukkan kitosan mampu mereduksi $\mathrm{ZnO}$ yang ditandai dengan terbentuknya serapan pada panjang gelombang yang berbeda-beda sesuai dengan kadar kitosan yang digunakan pada proses sintesis $\mathrm{Zn}$ nanopartikel, semakin besar absorbansi menunjukkan kondisi optimum dan perbandingan yang tepat kitosan dalam mereduksi $\mathrm{ZnO}$. Besar absorbansi berhubungan dengan jumlah nanopartikel yang terbentuk. Secara kualitatif, semakin tinggi nilai absorbansi dapat diasumsikan nano partikel yang terbentuk semakin banyak atau konsentrasi nano partikel dalam larutan semakin inggi [14]. Sedangkan berdasarkan hasil analisis dengan spektrofotometri serapan atom (SSA), diperoleh kadar zink dalam larutan hasil sintesis adalah 13,88 $\mathrm{mg} / \mathrm{L}$ yang menunjukkan bahwa kitosan telah mereduksi ion $\mathrm{Zn}$ yang ditandai dengan telah berkurangnya kadar zink dalam larutan hasil sintesis. Mekanisme reaksi yang terjadi antara kitosan dengan $\mathrm{ZnO}$ untuk menghasilkan nano partikel Zn ditunjukkan pada gambar 2.



Gambar 2. Mekanisme reaksi reduksi dari ion Zn menjadi nanpartikel Zn oleh kitosan

Secara umum spektra IR kitin dan kitosan memiliki serapan yang hampir sama, hanya terdapat perbedaan intensitas dan pergeseran serapan diantara spektra kitin dan kitosan. Yang perlu diperhatikan adalah perbandingan nilai absorbansi pita serapan dari spektrum inframerah pada bilangan gelombang $1655 \mathrm{~cm}$ 1 dan $3450 \mathrm{~cm}-1$. Pita serapan 1655 cm-1 merupakan pita serapan karbonil gugus Nasetil sedangkan pita serapan $3450 \mathrm{~cm}-1$ merupakan pita serapan gugus $\mathrm{NH}_{2}$.

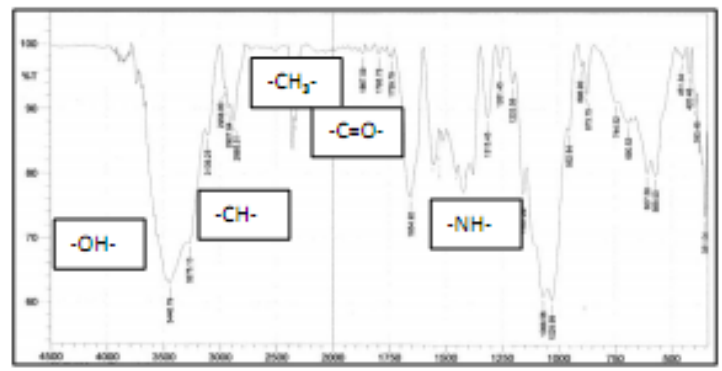

Gambar 3. Spektrum FTIR serbuk kulit udang

Pada analisis FTIR pada kulit udang standar (gambar 3) menandakan munculnya puncak absorbansi, yang terletak pada bilangan gelombang 3446,79 cm-1 yang menunjukkan adanya gugus $-\mathrm{OH}$, bilangan gelombang $3275,13 \mathrm{~cm}-1, \quad 3109,25 \mathrm{~cm}-1, \quad 2958,60 \mathrm{~cm}-1$, 2927,94 cm-1, dan $2885 \mathrm{~cm}-1$ menunjukkan adanya gugus $\mathrm{CH}$. 1795,73 cm-1, menunjukkan gugus $\mathrm{C}=\mathrm{O}$. Pada bilangan gelombang 1654,92 $\mathrm{cm}-1$ adanya gugus gugus $-\mathrm{NH}$ atau $\mathrm{NHCOCH}_{3}$. Sedangkan Gugus $-\mathrm{CN}$ ditunjukkan dengan munculnya puncak pada bilangan gelombang $1315,45 \mathrm{~cm}-1,1261,45 \mathrm{~cm}-$ 1, 1203,58 cm-1, $1068 \mathrm{~cm}-1$, dan $1029 \mathrm{~cm}-1$. 


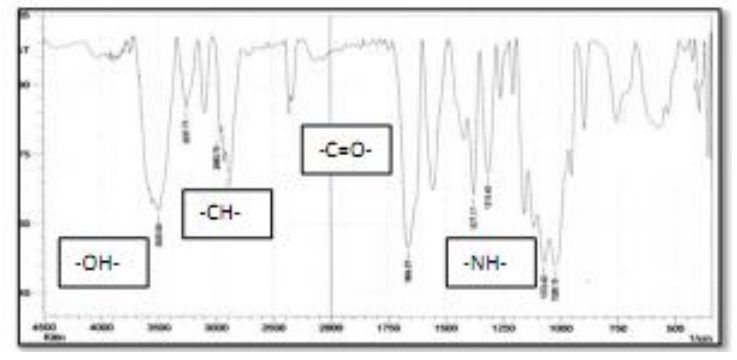

Gambar 4. Spektrum FTIR Kitin

Adapun analisis kitin dengan menggunakan FTIR (gambar 4) menunjukkan beberapa puncak, pada bilangan gelombang $3500,80 \mathrm{~cm}-1$ menandakan adanya gugus $-\mathrm{OH}$. Kemudian Terdapat puncak gugus karbonil dan gugus amida yang merupakan salah satu gugus fungsi yang dominan yang trrdapat pada kitin muncul pada bilangan gelombang 3257,77 $\mathrm{cm}-1,1664,57 \mathrm{~cm}-1$, dan pada $1315,45 \mathrm{~cm}-$. Sedangkan bilangan gelombang $2960,73 \mathrm{~cm}-1$ menunjukkanadanya gugus $-\mathrm{CH}_{3}$.

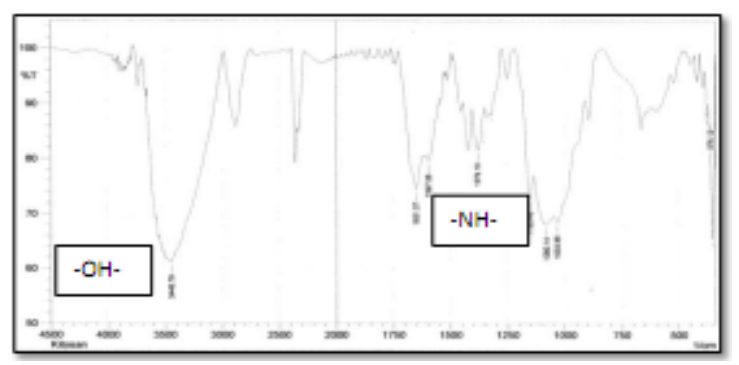

Gambar 5. Spektrum FTIR kitosan

Berdasarkan Hasil analisis FTIR Kitosan (gambar 5) diperoleh beberapa puncak, pertama pada bilangan gelombang $3446,79 \mathrm{~cm}-$ 1 yang menunjukkan adanya gugus $-\mathrm{OH}$ dengan intensitas yang kuat. Pada bilangan gelombang 1651,07 cm-1 dan 1597,06 cm-1, menunjukkan adanya gugus $-\mathrm{NH}_{2}$. Adapun beberapa gugus fungsi lain seperti $\mathrm{C}-\mathrm{H}$ muncul pada bilangan gelombang $2879,72 \mathrm{~cm}-1$, gugus $\mathrm{CH}_{2}$ pada bilangan gelombang $1340,53 \mathrm{~cm}-1$, gugus C-O pada bilangan gelombang 1153,43 cm-1 dan 1080,14 cm-1. Kemudian pada bilangan gelombang 1033,85 cm-1 menunjukkan gugus fungsi C-N. Terbentuknya kitosan ditandai dengan menurunnya Intensitas gugus karbonil amida $\left(-\mathrm{NHCOCH}_{3}\right)$ pada bilangan gelombang 1651,07 cm-1. Intensitasnya gugus karbonil menurun dibandingkan dengan dengan kitin karena telah terhidrolisis dengan bantuan basa kuat $\mathrm{NaOH}$ menjadi gugus amina.

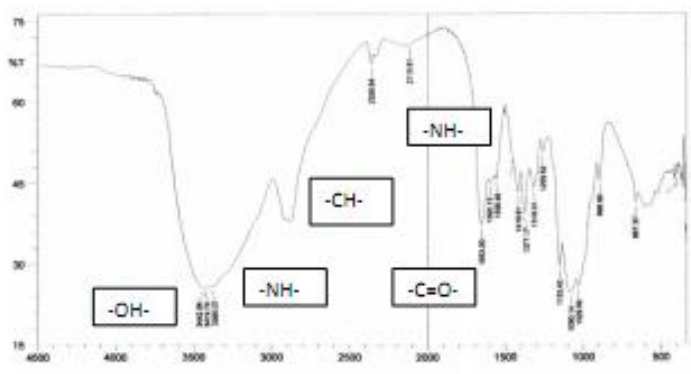

Gambar 6. Spektrum FTIR kitosan sebelum mereduksi

Pada spektrum FTIR kitosan hasil sintesis (gambar 6) muncul puncak serapan pada bilangan gelombang 3442,94 cm-1 menunjukkan serapan vibrasi ulur $-\mathrm{OH}$ yang tumpang tindih dengan vibrasi ulur $-\mathrm{NH}$. Pita serapan pada bilangan gelombang $3419,79 \mathrm{~cm}-$ 1 merupakan vibrasi $\mathrm{NH}$ amina primer yang diperkuatpada pita serapan 1595,13 cm-1. Pitapita serapan tajam pada biangan gelombang 2920,23 cm-1 dan 2879,72 cm-1 menunjukkan adanya gugus $\mathrm{C}-\mathrm{H}$ alkana, sedangakan munculnya gugus $\mathrm{C}-\mathrm{H}_{2}$ pada bilangan gelombang 1377 cm-1. C-O pada bilangan gelombang 1080,14 cm-1. Puncak absorbansi pada bilangan gelombang 1029,99 cm- 1 menunjukkan gugus fungsi C-N. Serapan pada bilangan gelombang $1653 \mathrm{~cm}-1$ adalah untuk rentang $\mathrm{C}=\mathrm{O}$ yang berasal dari gugus amida (NHCO-) yang menunjukkan bahwa pada kitosan hasil isolasi masih adanya gugus amida yang belumterdeasetilasi menjadi gugus amina [15].

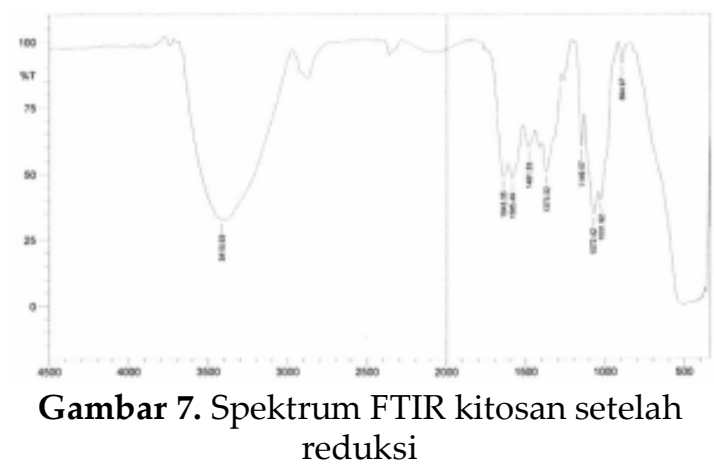

Gambar 7 merupakan spektrum FTIR dari kitosan setelah mereduksi ion $\mathrm{Zn}$. Terlihat adanya pergeseran bilangan gelombang spektrum dari kitosan sebelum dan sesudah 
mereduksi. Pada serapan 3415,93 cm-1 menunjukkan gugus $\mathrm{OH}$ dimana terjadi pergeseran bilangan gelombang dari 3442,94 cm-1. Pada serapan 1585,49 cm-1 menunjukkan gugus NH2, terjadi pergesaran bilangan gelombang dari 1595,13 cm-1. Pergeseran bilangan gelombang menunjukkan bahwa terjadi interaksi antara gugus $\mathrm{OH}$ dengan nanopartikel Zn, dikarenakan terjadinya proses oksidasi akibat proses reduksi nanopartiel Zn. Hal ini membuktikan bahwa kitosan mampu mereduksi Zn2+ menjadi $\mathrm{Zn}^{0}$.

Dari hasil pengukuran dengan PSA (Particle Size Analyzer) berdasarkan intensitas, angka, dan volume diperoleh ukuran rata-rata sebesar 213,41 nm. Dapat dikatakan bahwa nanopartikel zink berhasil disintesis karena sesuai dengan pengertian yang dijelaskan oleh [6] yaitu par tikel yang berbentuk padat dengan ukuran 10-1000 nm.
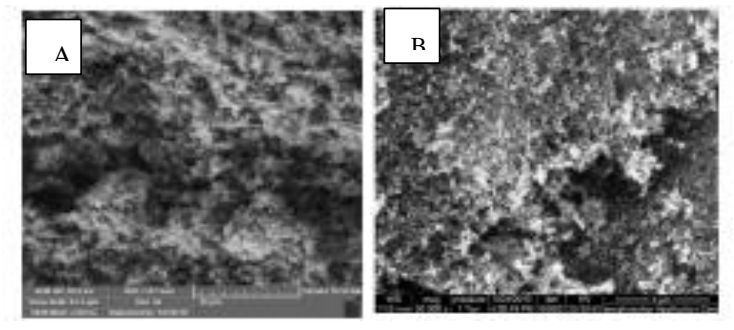

Gambar 8. Hasil SEM (A) Nanopartikel Zn (B) Nanopartikel ZnO

Morfologi sampel hasil sintesis dapat diamati dengan menggunakan instrumen SEM. Gambar 8B merupakan hasil SEM untuk nanopartikel $\mathrm{ZnO}$ yang berbentuk spheris dan bergranul [16]. Sedangkan gambar 8A merupaka hasil SEM nanopartikel Zn hasil sintesis yang menunjukkan bahwa nanopartikel yang dihasilkan berbentuk granular, berdempetan dengan partikel lainnya. Ukuran yang tidak seragam disebabkan oleh adanya agregasi pertikelpartikel zink.

\section{Kesimpulan}

Berdasarkan hasil penelitian diperoleh kesimpulan bahwa Kitosan mampu mereduksi $\mathrm{ZnO}$ menjadi nanopartikel $\mathrm{Zn}$ yang didasarkan pada hasil SSA diperoleh kadar Zn dalam larutan hasil sintesis sebesar 13,88 mg/L. Analisis dengan spektrofotometri UV-Vis diperoleh panjang gelombang maksimum
355,71 nm dan absorbansi sebesar 0,062. Karakterisasi Zn dengan menggunakan Particle Size Analyzer (PSA) diperoleh ukuran ratarata partikel sebesar 213,41 nm. Morfologi sampel yang dikeringkan dengan metode freeze drying yaituberupa serpihan sebagai akibat adanya kitosan yang membentuk lapisanatau coating karena reaksinya dengan asam asetat.

\section{DaftarPustaka}

1. Jayanti, R.; Leoanggraini, U.; Fermentasi Kitin dari Limbah Cangkang Kepiting Menggunakan Jamur Rhizopus Oryzae pada Berbagai Kadar Air. Fullerene Journal Of Chemistry,2020, 5(1), 10-15. doi:10.37033/fjc.v5i1.144

2. Amin, A.; Khairi, N.; Allo, E.;. Sintesis dan karakterisai kitosan dari limbah cangkang udang sebagai stabilizer terhadap $\mathrm{Ag}$ nanopartikel. Fullerene Journal Of Chemistry, 2019, 4(2), 86-91. doi:10.37033/fjc.v4i2.100

3. Purwanti, Ani, Evaluasi Proses Pengolahan Limbah Kulit Udang Untuk Meningkatkan Mutu Kitosan yang Dihasilkan, Jurnal Teknologi, 2014, Volume 7 Nomor 1, , 83-90.

4. Amri, K., Budidaya Udang Windu Secara Intensif, Agro Media, Jakarta. 2011

5. Agustina; Made, D. I; Nyoman, S. I; Isolasi Kitin, Karakterisasi, dan Sintesis Kitosan dari Kulit Udang, ISSN 1907-9850. 2015

6. Mohanraj, U.J; Chen, Y; Nanoparticles - A Review. Tropical Journal of Pharma-centical Research, 2006, 5(1): 561-573.

7. Ramahdita, G; Karakterisasi Nanopartikel $\mathrm{ZnO}$ Hasil Sintesis Dengan Metode Presipitasi dan Perlakuan Pra-Hidrotermal, Fakultas Teknik Program Studi Teknik Metalurgi Dan Material, Depok, 2011

8. Hargono, A; Sumantri, I; Pembuatan Kitosan Dari Limbah Cangkang Udang Serta Aplikasinya Dalam Mereduksi Kolesterol Lemak Kambing. Reaktor, 2008 12: 53-57

9. Wiyarsi, A.; Priyambodo, E; Pengaruh Konsentrasi Kitosan Dari Cangkang Udang Terhadap Efisiensi Penjerapan Logam Berat, Jurusan Pendidikan Kimia FMIPA Universitas Negeri Yogyakarta 2009 
10. Sugita, P.; Kitosan: Sumber Biomaterial Masa Depan. IPB Press, Bogor. 2009

11. Swastawati, F; Wijayanti, I; Susanto E.; Pemanfaatan Limbah Kulit Udang Menjadi Edible Coating Untuk mengurangi Pencemaran Lingkungan, Jurnal Teknologi Lingkungan Universitas Trisakti, 2008 Volume 4, No 4.

12. Arifin, Z.; Irawan, D.; Rahim, M; Sakti, L.D.; Produksi Kitosan Berbasis Limbah Udang Delta Mahakam: Tinjauan Proses Deasetilasi. Jurnal Riset Teknologi Industri, 2016. 6(11), pp.21-30.

13. Arifin, $Z$; Pemanfaatan Teknologi Sonikasi Tak Langsung Dalam Rangka Produksi Kitosan, Konversi, 2012, Volume 1, No 1 ,

14. Bakir, Pengembangan Biosintesis Nanopartikel perak Menggunakan Air Rebusan Daun Bisbul (Diospyros blancoi) untuk Deteksi Ion Tembaga (II) dengan Metode Kolorimetri, Skripsi, Program Studi S1 Fisika, Depok, 2011

15. Silverstein, R.M., Webster Fx., Kiemle DJ., , Spectrometric Identification of Organic Compounds, New York, 75, 2005

16. Singh, R.P.; Shukla, V.K.; Yadav, R.S.; Sharma, P.K.; Singh, P.K; Pandey, A.C.; Biological approach of zinc oxide nanoparticles formation and its characterization. Adv. Mater. Lett, 2011, 2(4), pp.313-317.

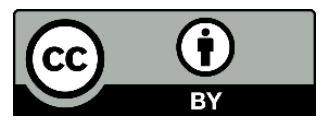

(C) 2020 by the authors. Licensee Fullerene Journal Of Chem. This article is an open access article distributed under the terms and conditions of the Creative Commons Attribution (CC BY) license

(http://creativecommons.org/licenses/by/4.0/). 